\title{
МИСТЕЦТВОЗНАВСТВО
}

\author{
DOI: https://doi.org/10.32839/2304-5809/2021-6-94-29 \\ УДК 7.03;7:001.12
}

Филиппова О.Н.

Политехнический музей (г. Москва)

\section{ПОРТРЕТ В ТВОРЧЕСТВЕ Н.И. ФЕШИНА (1881-1955)}

Аннотация. Творчество Николая Ивановича Фешина равно принадлежащее России и Америке, представляет одну из важных линий в развитии русского и европейского изобразительного искусства начала и первой половины XX века. Он был тесно связан с Казанью, где родился, учился в Казанской художественной школе. Казань конца XIX - начала XX века была университетским городом, с драматическим театром, музеем, в последнем находилась картинная галерея. В Казани этого времени работал целый ряд способных художников. Портретное наследие Н.И. Фешина казанского периода творчества во многом предопределило состояние живописи в Казани. Из Казани он уехал поступать в Императорскую Академию художеств в Санкт-Петербурге, где стал учеником И.Е. Репина, а после учебы снова вернулся туда преподавать в родную художественную школу. Спасаясь от тягот взбудораженной революцией жизни и по состоянию здоровья, он эмигрировал из Казани для лечения в США - 1 августа 1923 года. Американская география Н.И. Фешина - это Нью-Йорк (штат Нью-Мексико) и Калифорния (Лос-Анжелес).

Ключевые слова: творчество Н.И. Фешина, рисунки и композиционные эскизы, медали и премии, учитель, мастерство, портреты, картины, рисунки, модели, ученики, выставки передвижников, академик живописи.

Filippova Olga

Polytechnic Museum (Moscow)

\section{PORTRAIT IN THE CREATIVE WORK OF N.I. FESHIN (1881-1955)}

Summary. The creative work of Nikolai Ivanovich Feshin, which equally belongs to Russia and America, represents one of the important lines in the development of Russian and European fine art of the early and first half of the XX century. He was closely connected with Kazan, where he was born, studied at the Kazan Art School. Kazan of the late XIX - of the early XX century was a university city, with a drama theater, a museum, and an art gallery in the latter. A number of talented artists worked in Kazan at that time. The portrait heritage of N.I. Feshin of the Kazan period of creativity largely predetermined the state of painting in Kazan. From Kazan, he left to enroll in the Imperial Academy of Arts in St. Petersburg, where he became a student of I.E. Repin. Even during his studies at the St. Petersburg Academy of Arts, fate connected N.I. Feshin with the life and everyday life of the Mari people. Living for years in 1906 and 1907 in the Tsarevokokshaysky district of the Kazan province, in places near the villages of Kushni and Morki (now it is the Republic of Mari El), N.I. Feshin, coming into close contact with the life of the national village, made a number of sketches, sketches and sketches, "thus consolidating his impressions". He returned to Kazan after graduating from the Academy of Arts to teach at his native art school. Fleeing from the hardships of life agitated by the revolution and for health reasons, he emigrated from there to the United States for treatment-on August 1, 1923. N.I. Feshin's American geography is New York (New Mexico) and California (Los Angeles). Without N.I. Feshin, the picture of Russian art at the beginning of the XX century will not be complete, as well as American art of the 1920-ies and 1940-ies. However, the lack of significant collections of the artist's works in museums in Moscow and St. Petersburg, a restrained attitude towards the emigrant artist in the Soviet period, predetermined the underestimation of his work. The collection of the artist's works in the Kozmodemyansky Art and Historical Museum named after A.V. Grigoriev is the merit of A.V. Grigoriev himself - the founder of the museum. Alexander Vladimirovich, who dreamed of creating the "second Tretyakov Gallery on the Volga" in his homeland, repeatedly noted that "the most valuable works in the museum are the works of N.I. Feshin, A.E. Arkhipov, V.N. Baksheev", famous painters who played an important role in the formation of A.V. Grigoriev as an artist and as a person. To date, the museum has eleven (nine paintings and two graphic) works of the artist, made by N.I. Feshin before his departure to America.

Keywords: the creative work of N.I. Feshin, drawings and composite sketches, medals and awards, teacher, skill, portraits, paintings, drawings, models, students, exhibitions of peredvizhniki, academician of painting.

Постановка проблемы. Живописное да-

1 рование Николая Ивановича Фешина проявилось в жанровой картине, в пейзаже и натюрморте. Однако наиболее сильной и яркой частью искусства Н.И. Фешина является портрет. Изысканная сдержанность и вместе с тем насыщенность цветовой гаммы, разнообразие фрактуры, острота видения характера модели определяют своеобразие портретов Н.И. Фешина. Даже при самом благожелательном отношении к портретируемому Н.И. Фешин не допускает ни малейшей идеализации или какого-нибудь смягчения черт лица или особенностей характера.

Анализ последних исследований и публикаций. Одним из первых исследователей, посвятивших небольшую книгу этому художнику, был П.И. Дульский. Он вышла в 1921 году в Казани. Автор рассматривает казанский период творчества художника. Эта работа представляет интерес внимательным изучением био- 
графиии и творчества Н.И. Фешина, анализом техники живописи. Статьи о Н.И. Фешине, появившиеся в американских журналах, не дают научного анализа творчества художника. Они содержат подробные биографические сведения, изложенные иногда необъективно. Такой характер носят статьи о Н.И. Фешине Фрэнка Уотерса в журнале "Аризона» за фревраль 1952 года и Марианны Бурлюк в журнале «Цвет и ритм» за 1958 год (№ 35) [1; 10]. В статье Марианны Бурлюк интересны воспоминания о процессе работы Н.И. Фешина над некоторыми портретами. «Второе» открытие Н.И. Фешина для соотечественников произошло в 1958 году, когда искусствовед Галина Аркадьевна Могильникова создала первую экспозицию произведений художника в залах картинной галереи ГМ ТАССР.

Она инициировала и организовала крупнейшие персональные выставки художника в 19631964-х годах в Москве, Ленинграде, Казани и других городах СССР, которые сопровождались изданием ею составленных каталогов. Она же организовала изучение и приобретение произведений Н.И. Фешина в собрание ГМИИ РТ, ею был издан в 1975 году сборник документов, писем и воспоминаний о художнике, организована в 1976 году совместная русско-американская выставка произведений Н.И. Фешина, собран самый крупный в России архив художника [6]. И как один из завершающих итогов - создание мемориального зала Н.И. Фешина, ставшего визитной карточкой ГМИИ РТ. Поскольку об Н.И. Фешине не так часто вспоминали, к тому же он уехал за границу в 1923 году, то творчество этого большого мастера было недостаточно изучено. Цель данной публикации - раскрыть портретное наследие Н.И. Фешина, проанализировать его работы.

Николай Иванович Фешин родился 26 ноября (9 декабря) 1881 года в г. Казани. Обстановка, в которой рос мальчик, способствовала развитию в нем интереса к искусству. Его отец был прекрасным резчиком по дереву. Он имел мастерскую, в которой будущий художник с увлечением рисовал, занимался резьбой, вычерчивал узоры. В летнее время он вместе с мастеровыми отца выезжал в уездные села для выполнения заказов. Дремучие леса Заволжья, широта волжских просторов, встречи с крестьянами-чувашами, марийцами, русскими, их манера говорить, одежда, быт и обычаи оставили в душе впечатлительного мальчика глубокий след, и в дальнейшем не раз служили источником вдохновения. Отец поддерживал увлечение сына искусством и мечтал даже устроить его к какому-нибудь художнику. В 1895 году в Казани открылась Художественная школа, сыгравшая значительную роль в воспитании художников-реалистов. Н.И. Фешин поступил в школу и скоро обратил внимание преподавателей своими интересными композициями на бытовые темы.

В 1901 году Н.И. Фешин, как лучший выпускник школы, был принят в Высшее художественное училище при Петербургской Академии художеств. Рисунки и композиционные эскизы, которые выполнил Н.И. Фешин в академическое годы, не раз поощрялись Советом Академии, а медали и премии, полученные им за учебные программы, говорили о росте мастерства художника. Последние годы пребывания в Академии Н.И. Фешин провел в мастерской И.Е. Репина, под влиянием его учителя и формировалось его мастерство. Его портреты 1907 года уже совершенно своеобразны и по цветовому строю, и по чисто индивидуальной фешинской ценности видения человека, и по неожиданному построению композиции. С первых лет самостоятельной творческой деятельности художник находит своеобразную технику. Он работает на казеиновом грунте, который обусловливает матовую поверхность картин и портретов. Художник часто пишет очень широко, порой используя мастихин вместо кисти. На лицо в портрете Н.И. Фешин накладывает иногда краску пальцем, создавая гладкую поверхность, контрастирующую со свободой широкого мазка на одежде и фоне. Цветовое решение лучших фрешинских портретов отличается разнообразием колорита. Н.И. Фешин писал людей, которых хорошо знал. Много раз с уважением и любовью писал он своего отца - Ивана Алексеевича, который переехал из Арзамаса в Казань, где и родился Н.И. Фешин. У Ивана Алексеевича была позолотно-столярно-резная мастерская. Это был превосходный мастер своего дела. Еще мальчиком Н.И. Фешин находился под большим влиянием художественных интересов отца, в мастерской которого он рисовал, резал по дереву.

Н.И. Фешин также написал портреты брата, матери, жены, лирические и нежные дочери, многочисленные портреты учениц Казанской художественной школы, художников, архитекторов. Еще будучи в Академии, он приобретает широкую известность не только как портретист, но и как автор ряда своеобразных картин.

События револющии 1905 года отразились в картине "Случайная жертва", которая была удалена с выставки как произведение на революционную тему [5, с. 278]. А также в эскизе «Усмирили» и в ряде рисунков сатирического журнала «Леший» [5, с. 278]. В журнале «Леший» его рисунки появляются наряду с работами П.С. Добрынина, И.А. Бродского, А.М. Любимова $[5$, с. 278$]$. Один из них был рисунок «Встреча со стражником» [5, с. 278]. Он был размещен в журнале в годовщину Кровавого воскресенья, 9 января. Мы видим во мгле вечерней улицы измученных женщин, которые подступают к стражнику. Протест против кровавых правонарушений правительства здесь выражен очень резко и прямолинейно. Первым произведением, принесшим Н.И. Фешину известность, был этюд «Портрет неизвестной (Дама в лиловом)» (1908) [5, с. 278] (илл. 1).

На Международной выставке в Мюнхене художник получил за эту работу Малую золотую медаль. В «Портрете неизвестной (Дама в лиловом)», написанном на серебристом фоне, нет подробного рассказа о человеке, дается лишь несколько основных характерных черт облика [5, с. 278]. Мы здесь видим даму в светло-сиреневом платье, с белым шарфом и в длинных белых перчатках. На коленях у нее муфта из светлого соболя. Мягкие каштановые пушистые волосы собраны в низкий пучок. Очень выразительны ее руки с длинными гибкими пальцами. Мер- 


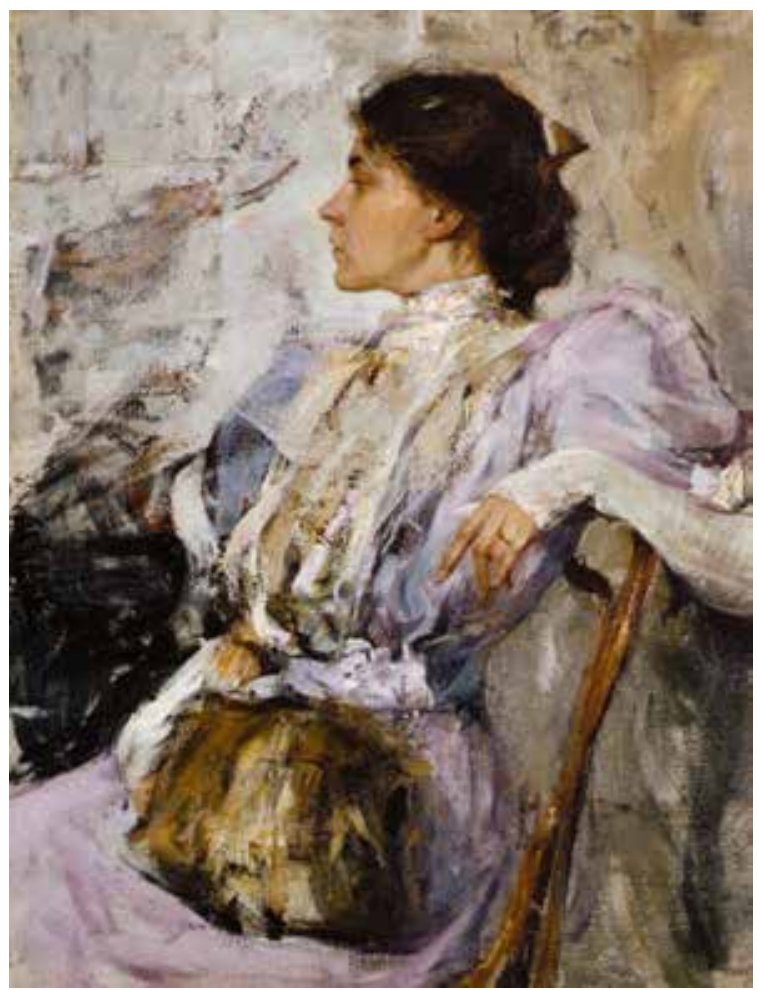

Илл. 1. Н.И. Фешин. «Портрет неизвестной (Дама в лиловом)». 1908 г. Холст, масло, $102,0 \times 79,0$ см // Государственный Русский музей (г. Санкт-Петербург)

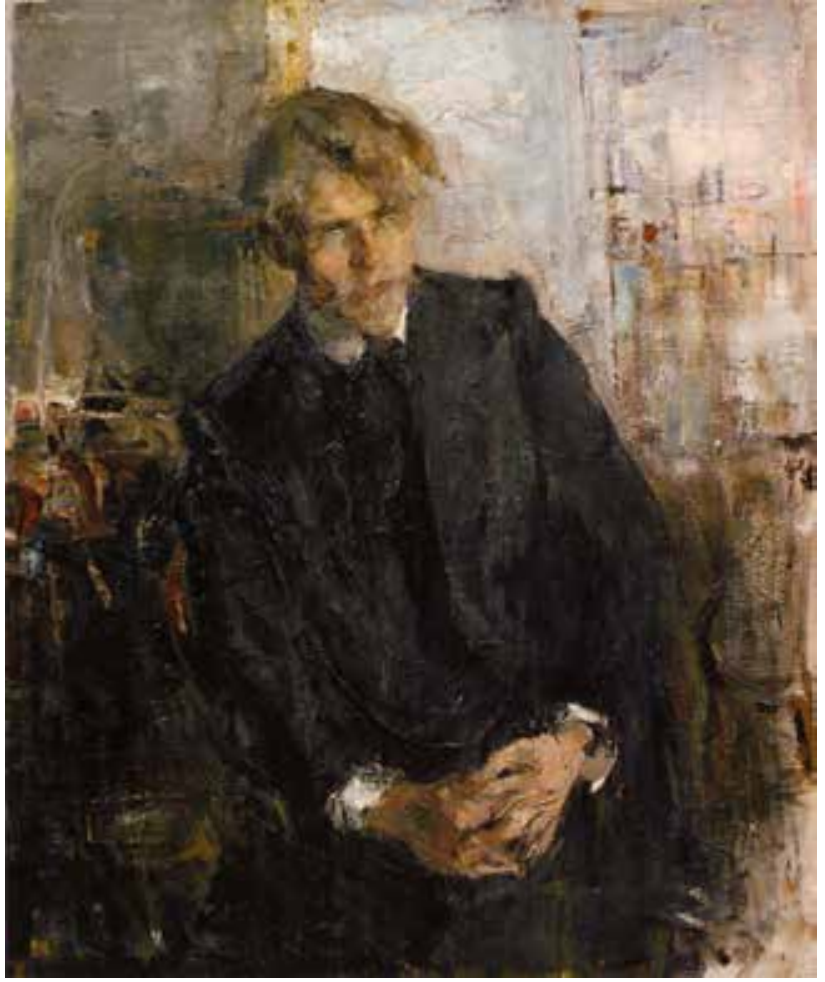

Илл. 2. Н.И. Фешин. «Портрет художника Константина Михайловича Лепилова". 1909 г. Холст, масло, 113,0 × 93,3 см // Государственный Русский музей (г. Санкт-Петербург) цание серебристого фрона достигнуто широким, свободным письмом, верным мазком почти однородного серебристого цвета на более темном слое (видимо, что портрет был написан на старом холсте). В этой работе художник с вниманием изучает индивидуальные черты модели.

Обостренное внимание к индивидуальности человека, порой в ущерб обобщению и типизации, было одной из тенденций фрешинских портретов. Вообще, портреты Н.И. Фешина этой поры были очень разнообразны. Свободно и широко выполненный станковый портрет, портрет-этюд неожиданно перемежаются с портретом-миниатюрой. Почти миниатюра был портрет брата художника Павла Ивановича Фешина (сам портрет может быть датирован по воспоминаниям П.И. Фешина - брата художника), которому было в то время двадцать лет. Показано юношеское лицо с голубыми глазами и высоким выпуклым лбом. Один взмах кисти передает ослепительно белый воротничок. Портрет написан на франере, на любимом Н.И. Фешиным казеиновом грунте в мягкой приглушенной цветовой гамме. Художнику удалось проникновенно уловить самую сущность внутреннего мира человека - его чистоту, духовную ясность, скромность, которые брат художника сохранил до старости. Внимание к душевному миру человека было характерно для лучших портретов Н.И. Фешина. Цветовые искания, поиски новых технических приемов в его работе имели существенное значение. Глубокой задумчивостью был пронизан «Портрет художника Константина Михайловича Лепилова» (1909, ГРМ) (илл. 2).

Художник сидит, склонив голову. Он погружен в какие-то думы. Тонкие, нервные пальцы его сплетены. Руки в портретах Н.И. Фешина выразительны. Он рисует их с особым вниманием. В «Портрете К.M. Лепилова» мы видим одухотворенное лицо с тонкими чертами, легкие русые волосы, падающие на лоб, и нервно сплетенные пальцы рук создают характеристику человека умного, тонкого, возможно нерешительного и мягкого [5, с. 281].

Портрет выдержан в коричнево-серой гамме. Чуть поблескивают очки в золотой оправе. Фон справа высветляется и становится жемчужно-серым. Портрет выполнен широко и пастозно. Лицо смоделировано более мягко и написано в иной манере, чем одежда и фрон. Близок по лирической проникновенности портрету Константина Михайловича Лепилова - «Портрет Павла Александровича Радимова» (1910, собрание П.А. Радимова), ученика Н.И. Фешина по Казанскому училищу (илл. 3).

«Писал меня Н.И. Фешин, - рассказывает П.А. Радимов, - недели две. Во время работы разговаривать не любил. Писал через день, по чуть влажному. Белила на ночь выдавливал на бумагу и писал загустевшей краской, растирая пальцами комья» [5, с. 281]. У П.А. Радимова на портрете молодое лицо с задумчивым взглядом синих глаз. Темно-каштановые волосы падают на широкий лоб, четко очерчены полные губы. Лицо молодого художника привлекает национальной русской красотой. Портрет написан в приглушенной серебристой гамме. Сочетание серо-охристого фона и белой рубахи красиво. Одна из основных особенностей живописи Н.И. Фешина в том, что его интересуют пленэрные задачи и в портрете. Насыщен солнцем 


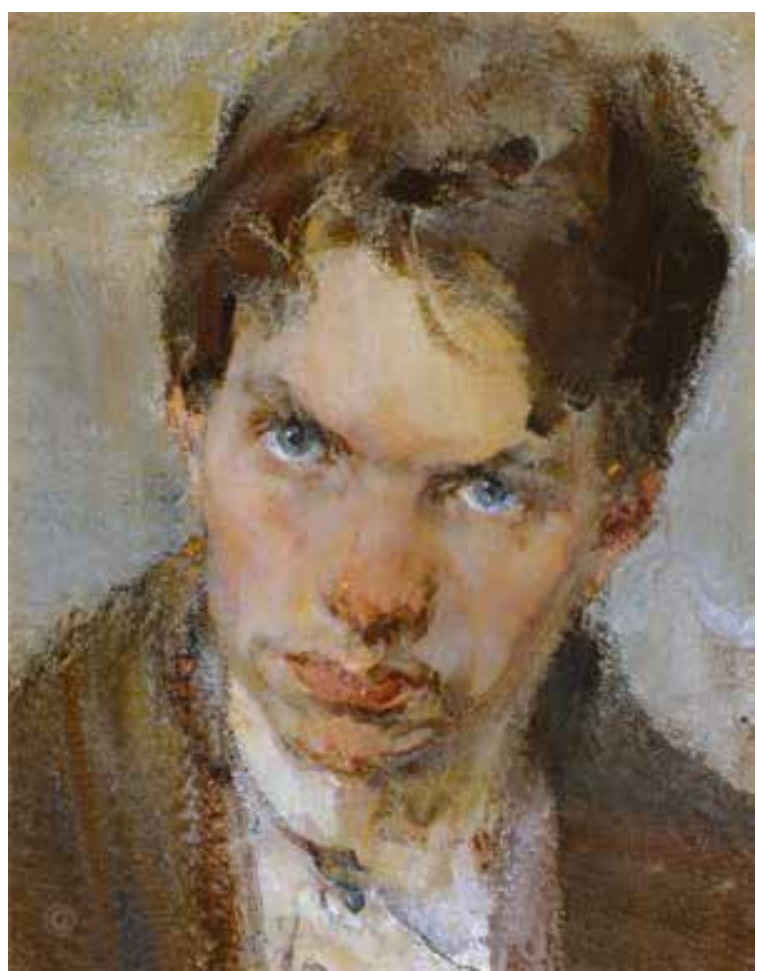

Илл. 3. Н.И. Фешин. «Портрет

Павла Александровича Радимова". 1910 г. Холст, масло, $30,8 \times 24,5$ см $/ /$

Собрание П.А. Радимова (г. Москва)

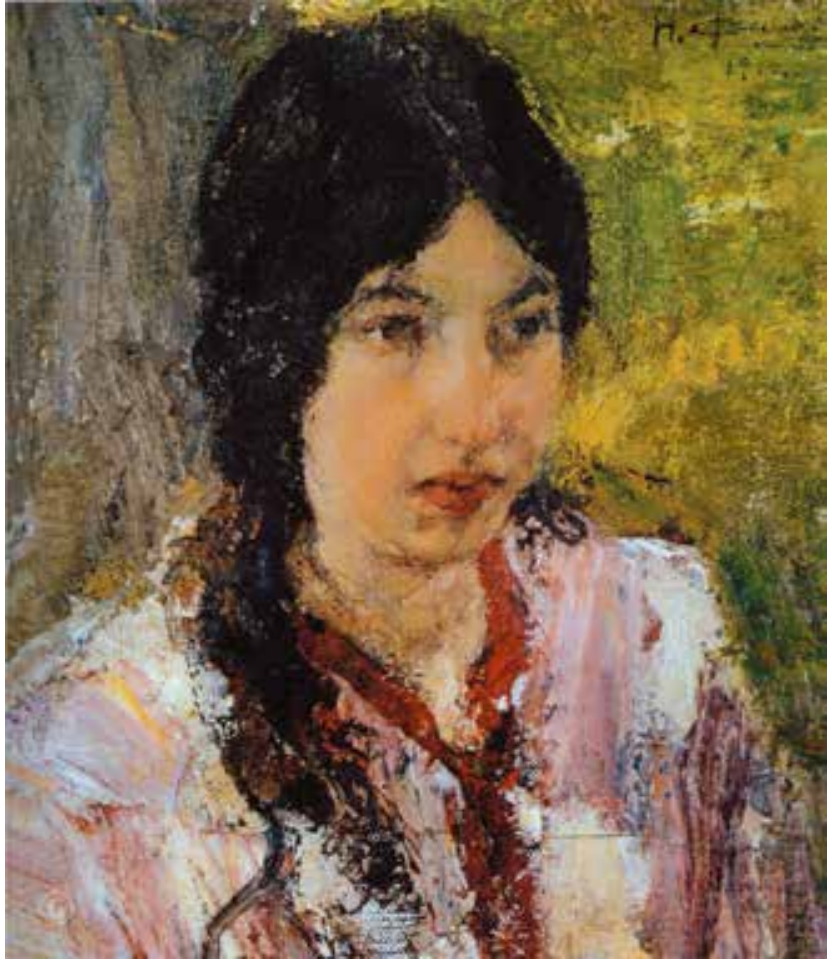

Илл. 4. Н.И. Фешин. «Портрет Марии Григорьевны Медведевой». 1912 г. Холст, наклеенный на дерево, масло, 24,5 × 23,5 см // Государственный

Русский музей (г. Санкт-Петербург)

зрачный, как капля воды. Лицо задумчивое, внимательное и проникновенное. Несмотря на некоторую стилизацию в костюме и освещении, несмотря на доброжелательное отношение к портретируемой, Н.И. Фешин остается верным сам

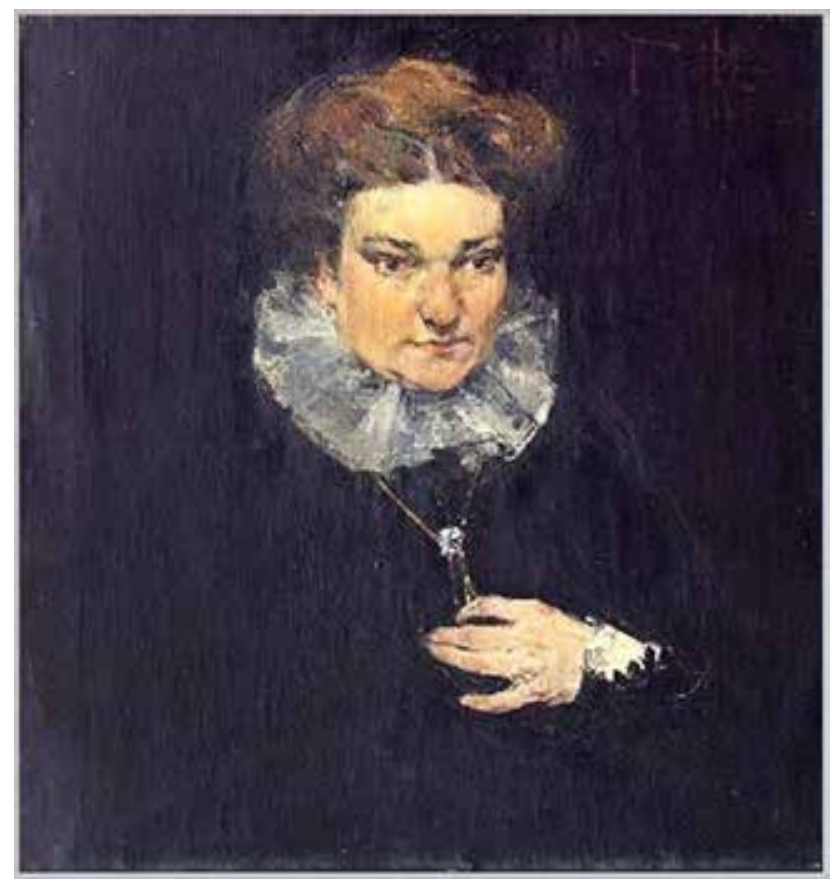

Илл. 5. Н.И. Фешин. «Портрет Серафимы Михайловны Адоратской». 1910 г. Холст, масло, 71,0 × 65,0 см // Государственный музей изобразительных искусств Республики Татарстан (г. Казань) 


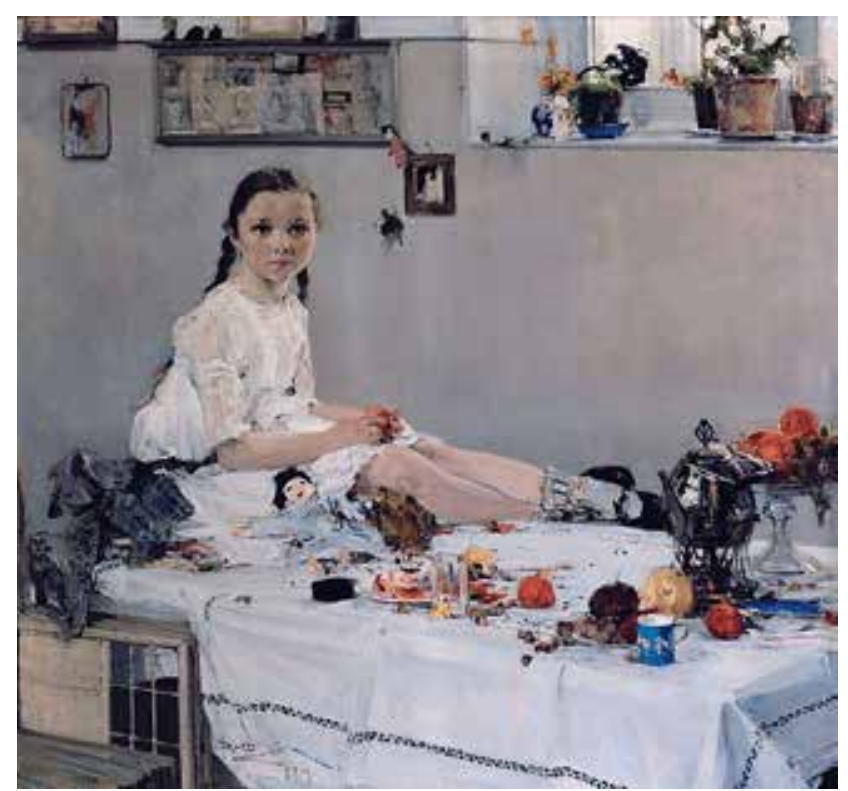

Илл. 6. Н.И. Фешин. «Портрет Вари Адоратской». 1914 г. Холст, масло, $135,0 \times 145,0$ см //

Государственный музей изобразительных искусств Республики Татарстан (г. Казань)

себе - он замечает и чуть обвисший подбородок, и искривленность больших пальцев. Портрет написан в темной красочной гамме. Одежда почти сливается с фоном. Из полумрака выступают лицо, обрамленное мерцающим темным золотом волос, рука и белое жабо. Совершенно в иной цветовой гамме, светлой и радостной, решен «Портрет Вари Адоратской» (1914, ГМИИ РТ) (илл. 6).

По мнению В.В. Адоратской, «портрет был написан весной, в казанской мастерской H.M. Сапожниковой, где так любил работать Н.И. Фешин. В мастерской был верхний свет и спокойный серый цвет стен» [5, с. 282]. Мы видим девочку в белом батистовом платьице с голубовато-зеленым бантом, которая сидит на столе, в просторной светлой комнате. На столе прекрасно написанный натюрморт. Никелированный чайник на спиртовке, апельсины, гранаты, орехи, ваза

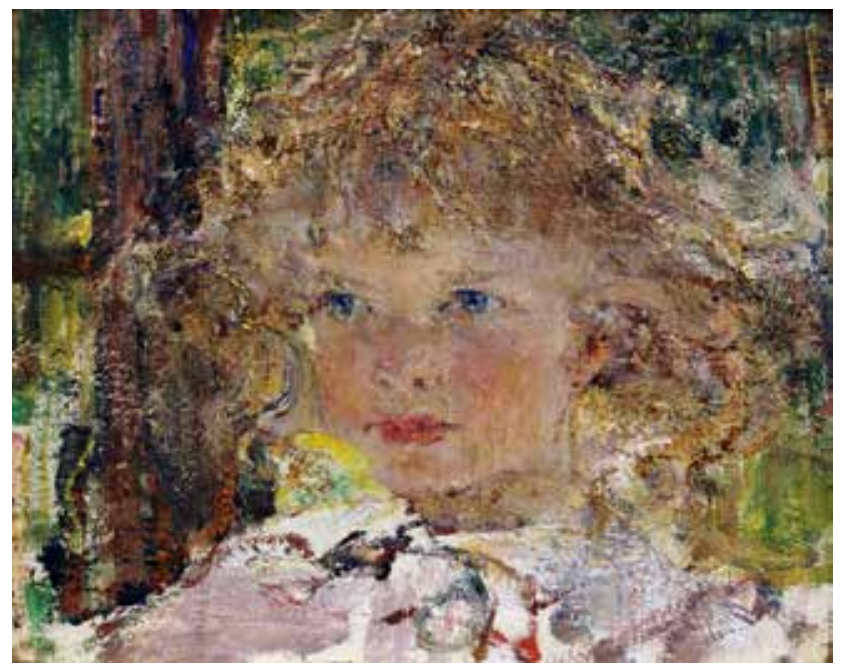

Илл. 7. Н.И. Фешин. «Портрет дочери Ии». 1917 г. Холст, масло, 23,8 × 29,5 см // Государственный музей изобразительных искусств Республики Татарстан (г. Казань) с фрруктами и кукла в голубом платьице. Все это словно бы внезапно было увидено художником. Портрет интересен не только цветовым решением, но и серьезностью, и душевной мягкостью образа. Портрет этот, выполненный в несколько сеансов, работа над ним продолжалась около трех недель, вызывает в памяти лучшие детские портреты русской живописи второй половины XIX века (на примере известного полотна В.А. Серова «Девочка с персиками»).

В этих двух произведениях действительно много общего. Объект изображения, выразительные средства, но главное - настроение, та атмосфера равновесия, гармонии и счастья, которая составляет сущность обоих образов. Лирические ноты звучат в портретах дочери Ии. Ее Н.И. Фешин писал много раз, но мы остановимся на портрете 1917 года (илл. 7).

На пленэрном этюде из собрания Дульской (г. Казань) мы видим большие и серьезные голубые глаза девочки, которые внимательно смотрят куда-то вдаль. Яркие лучи солнца золотят волосы, создают лучезарный ореол вокруг ее лица. Н.И. Фешин замечает очертания вздернутого носика и пухлых розовых губ четкого рисунка. Большой белый воротник оттеняет нежный цвет детского лица, на розоватой кофте золотисто-зеленые отблески. В почти гладкой фактуре написано лицо, широко и пастозно волосы. Вообще, в своих портретах детей Н.И. Фешин ярко раскрывает индивидуальные особенности характера. Так, им был начат интересный «Портрет Миши Бардукова», сына художницы Марии Михайловны Бардуковой (1912, ГМИИ РТ) (илл. 8).

На большом холсте был начат портрет свободно расположившегося на тахте мальчика. Намечена была лишь голова и несколько мазков брошены на фрон. Волосы были написаны быстрыми, тремя-четырьмя мазками широкой кисти.

Мы видим здесь капризного, избалованного ребенка. В портрете сочетаются индивидуальные черты характера с какими-то общими для многих детей, испорченных чрезмерной роди-

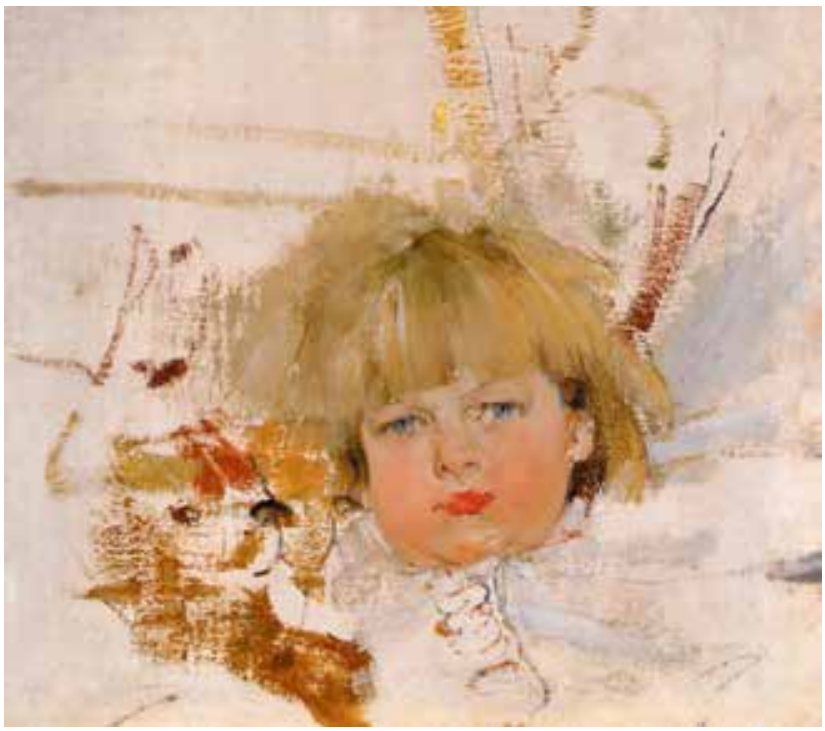

Илл. 8. Н.И. Фешин. «Портрет Миши

Бардукова". 1914 г. Холст, масло, 51,0 × 47,0 см // Государственный музей изобразительных искусств Республики Татарстан (г. Казань) 


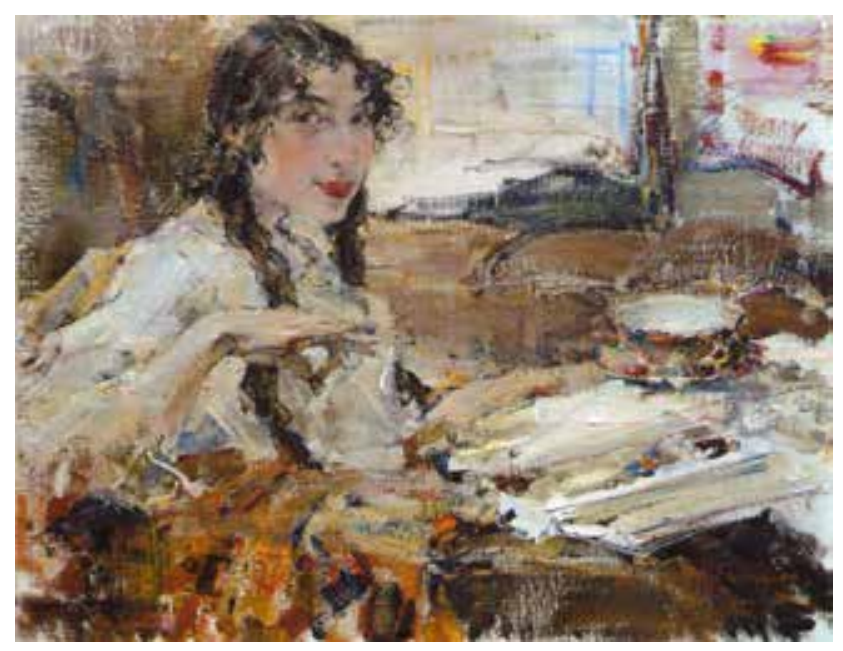

Илл. 9. Н.И. Фешин. «Портрет

Тамары Александровны Поповой». 1917 г. Холст, масло, 39,8 × 51,5 см // Государственный музей изобразительных искусств Республики Татарстан (г. Казань)

тельской опекой. Впоследствии из большого холста была вырезана часть с головой мальчика, о композиционном построении портрета мы можем судить лишь по рассказам В.В. Адоратской. Художник-лирик чувствуется в портрете жены художника с дочерью за раскрытой книгой. Ие в это время было не больше пяти лет, что дает возможность датировать работу 1915-1916 годами. Мать ласково прижалась к ребенку. Девочка смотрит на пишущего ее отца. Художник передал и тихую, словно затаенную нежность в серьезном, пытливом взгляде ребенка, и глубину материнской любви. Лиризм, мастерское живописное выполнение делают эту работу одним из лучших решений темы материнства у Н.И. Фешина. 1916-1917-е годы - были очень плодотворными в творчестве Н.И. Фешина-портретиста. В своих лучших работах художник приходит к обобщению в портрете. В это время он создает острые психологические портреты - профрессора Л.Л. Фофранова, художника В.Г. Тихова, отца. Пытливо ищет он каких-то новых форм в решении портрета-картины. Иногда эти поиски оказываются спорными, порой противоречивыми, порой художник сбивается на салонное решение. Таков, например, его «Портрет Тамары Александровны Поповой» (1917), где художник любуется красотой модели, но допускает некоторую нарочитость жеста (илл. 9).

Интерес к быстрому портретному этюду был характерен для Н.И. Фешина этой поры. Привлекали художника и передача постоянно меняющегося облика человека, схваченного в какоето краткое мгновение, и возможность быстрого свежего живописного решения.

В 1916 году Н.И. Фешин постоянно пишет H.M. Сапожникову. Были написаны и быстрые этюды за чтением и большие портреты. Н.М. Сапожникова - ученица Н.И. Фешина по Казанскому училищу живописи. Женщина умная, образованная, одаренная, она была старше Н.И. Фешина и в свою очередь обучала его языкам. В Казани, в доме промышленника М.Ф. Сапожникова, была построена мастерская с верх-

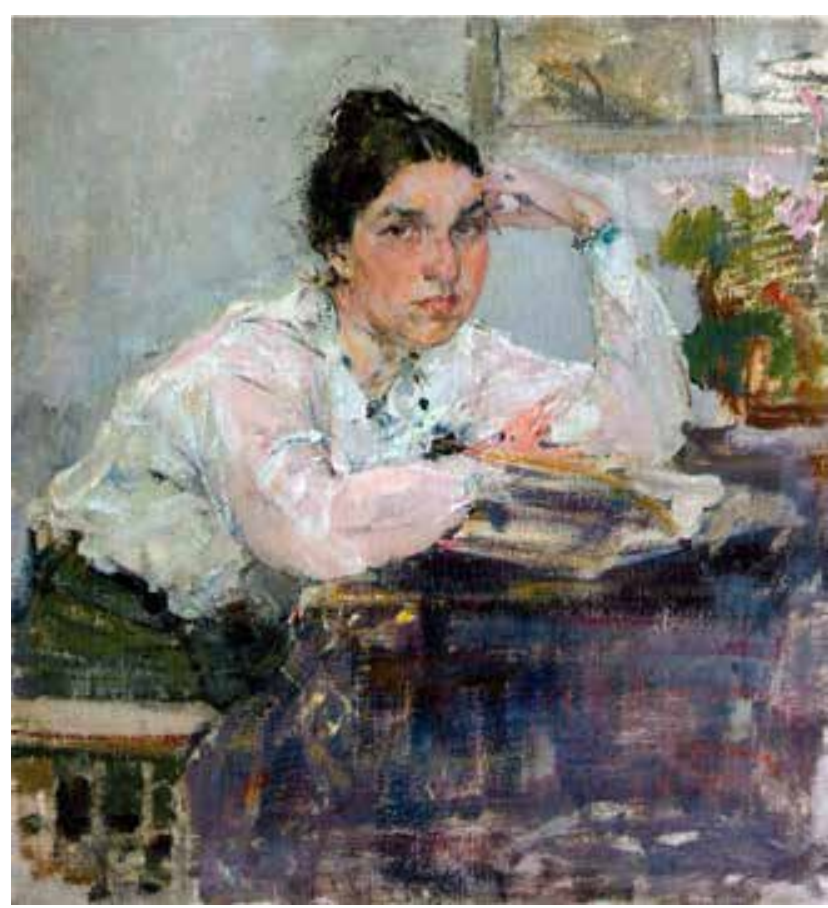

Илл. 10. Н.И. Фешин. «Портрет

Надежды Михайловны Сапожниковой». 1916 г. Холст, масло, 121,0 × 131,0 см // Государственный музей изобразительных искусств Республики Татарстан (г. Казань)

ним светом, где очень любил писать Н.И. Фешин. H.M. Сапожникова покровительствовала художнику: он в это время очень нуждался в ее покровительстве. Портреты сестры, племянницы, свои она покупала по самым высоким ценам. По рассказам В.В. Адоратской, Н.М. Сапожникова была женщина деятельной, с несколько мужским характером. Она жила интересной, содержательной жизнью, много путешествовала. Энергичной, подтянутой, в строгой английской блузе, она предстает перед зрителем в быстрых портретных этюдах 1915-1916 годов. В одном из них 1916 года Н.M. Сапожникова была изображена за чтением (илл. 10).

Тонкими пальцами она перебирает задумчиво бусы. Хотя этюд быстрый и не отличается завершенностью станковых портретов, руки Н.И. Фешин пишет с характерной для него пластичностью и мастерством. Портрет построен на градациях серого цвета. На втором портрете того же 1916 года та же модель изображена у стола, она в упор, серьезно и внимательно смотрит на зрителя (илл. 11).

Ее энергичное волевое лицо с карими умными глазами художник мягко моделирует. Иной характер носят большие композиционные портреты той же модели, которая позировала в спещиально сшитом для этого случая, по эскизу Н.И. Фешина, белом платье. Цветовой строй портрета заранее продумывался Н.И. Фешиным. Старинный фрранцузский веер, который держит в руках Н.M. Сапожникова, белые перчатки, брошенные на клавесин, - необходимые компоненты целостного и единого колористического строя, гармоничного и сдержанного. Сама модель с карими глазами, проницательными и умными, изображена на фоне золотистой стены. Нельзя 


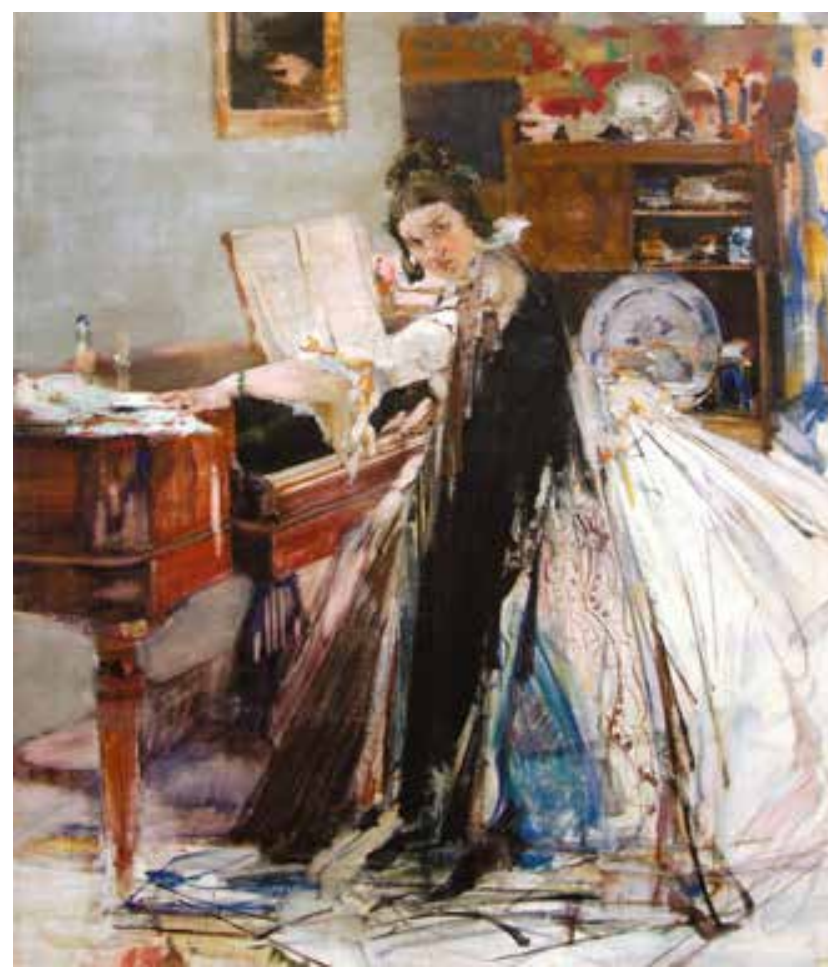

Илл. 11. Н.И. Фешин. «Портрет Надежды Михайловны. У рояля». 1916 г. Холст, масло, $178,0 \times 159,0$ см // Государственный музей изобразительных искусств Республики Татарстан (г. Казань)

не отметить неудачное сочетание орнаментального плоского фона, фрона, выполненного по трафрарету, и очень широко и пластично написанных фоигур, клавесина. Белое платье из тонкой легкой ткани, на него наброшена шаль, которая чуть приглушена по цвету в сравнении с натурой. Рука, гибкая и сильная, непринужденно

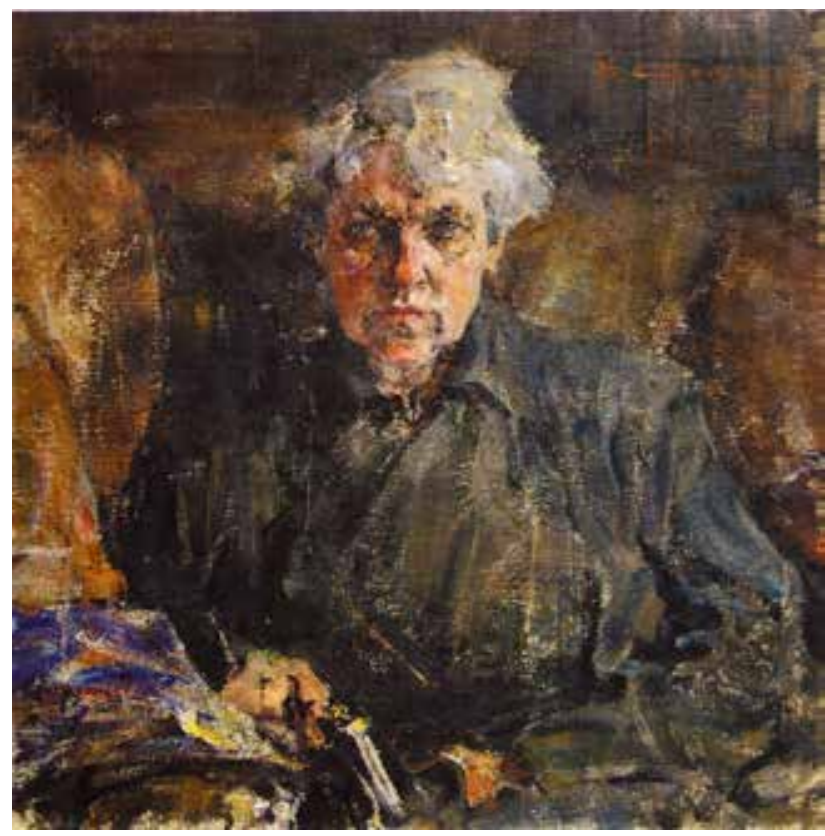

Илл. 12. Н.И. Фешин. «Портрет

Е.М. Конуриной». 1917 г. Холст, масло, 71,0 × 71,0 см // Государственный музей изобразительных искусств Республики Татарстан (г. Казань) играет веером. Динамичен по композиции второй большой портрет Н.M. Сапожниковой. Она, словно бы внезапно приостановив игру на клавесине, обернулась к художнику, облокотившись красивой полной рукой о крышку. Композиция портрета свободна, фригура непринужденно заполняет холст излюбленного художником почти квадратного формата. Нельзя не отметить некоторой нарочитой манерности жеста. Портрет был не закончен, и это дает возможность проследить процесс его создания.

Смело намечена углем фигура и быстро прописана энергичными длинными мазками по контуру (правая часть платья осталась незаконченной). Лицо и руки тем не менее смоделированы внимательно и написаны с характерной для Н.И. Фешина широтой и пластичностью. В 1916-1917-е годы Н.И. Фешин выполняет разнохарактерные женские портреты. Его привлекает и молодая лукавая Т.А. Попова (1917, ГМИИ РТ), и Е.М. Конурина с несколько мужского склада старым и умным лицом (1917, ГМИИ РТ) (илл. 12).

E.M. Конурина прожила трудную жизнь. Н.И. Фешин встречал ее у Сапожниковых. Он написал ее в глубоком кожаном кресле. Портрет выдержан в серо-охристо-зеленоватой гамме. У нее серая блуза мужского покроя, стриженые седые волосы. Лицо контрастно освещено справа. В руке только что закрытая книга. Взгляд светло-серых, чуть зеленоватых глаз устремлен прямо на зрителя. Е.М. Кокурина, судя по рассказам В.В. Адоратской, была умной, передовой женщиной, она обладала большой энергией и сильным характером, организовала школу, лечила крестьян. Художнику, думается, удалось передать в портрете образ много пережившей и умудренной большим жизненным опытом старой женщины. Совершенно в ином эмоциональном ключе решен портрет Т.А. Поповой - ученицы Казанской художественной школы. Этот портрет был выдержан в светлой, яркой цветовой гамме. Черноглазая молодая художница сидит на тахте. На низком столике перед ней раскрытая книга и яркая чашка. Красиво переливается перламутром белый цвет. Т.А. Попова изображена на фроне светлого окна, в белой кофточке с наброшенной зеленовато-оранжевой шалью.

У нее черные пушистые волосы, заплетенные в косы, нежный румянец, сильный разлет черных бровей и ярко-карминные губы. Легкий, может быть, чуть манерный жест руки излишне приковывает внимание зрителя. В 1916-1918-х годах были выполнены портреты, которые по психологической остроте и обобщенности образа можно считать этапными в творчестве художника. Таков его «Портрет отца» 1918 года, как один из самых ярких образов в его творчестве [8, с. 19] (илл. 13).

Отец художника изображен сидящим на подлокотнике массивного кресла в интерьере, так, что надетый на нем тулуп кажется не очень мотивированным мизансценой, выбранной автором. Но как в классических парадных портретах камзолы, фрраки и регалии обозначали социальный статус, так и здесь тулуп нужен, чтобы создать исполненный внутренней значимости образ русского мастерового. Н.И. Фешин подчеркивает кряжистую крепость человека, вся жизнь которого - это труд, дающий и устойчивость, и мудрость, 


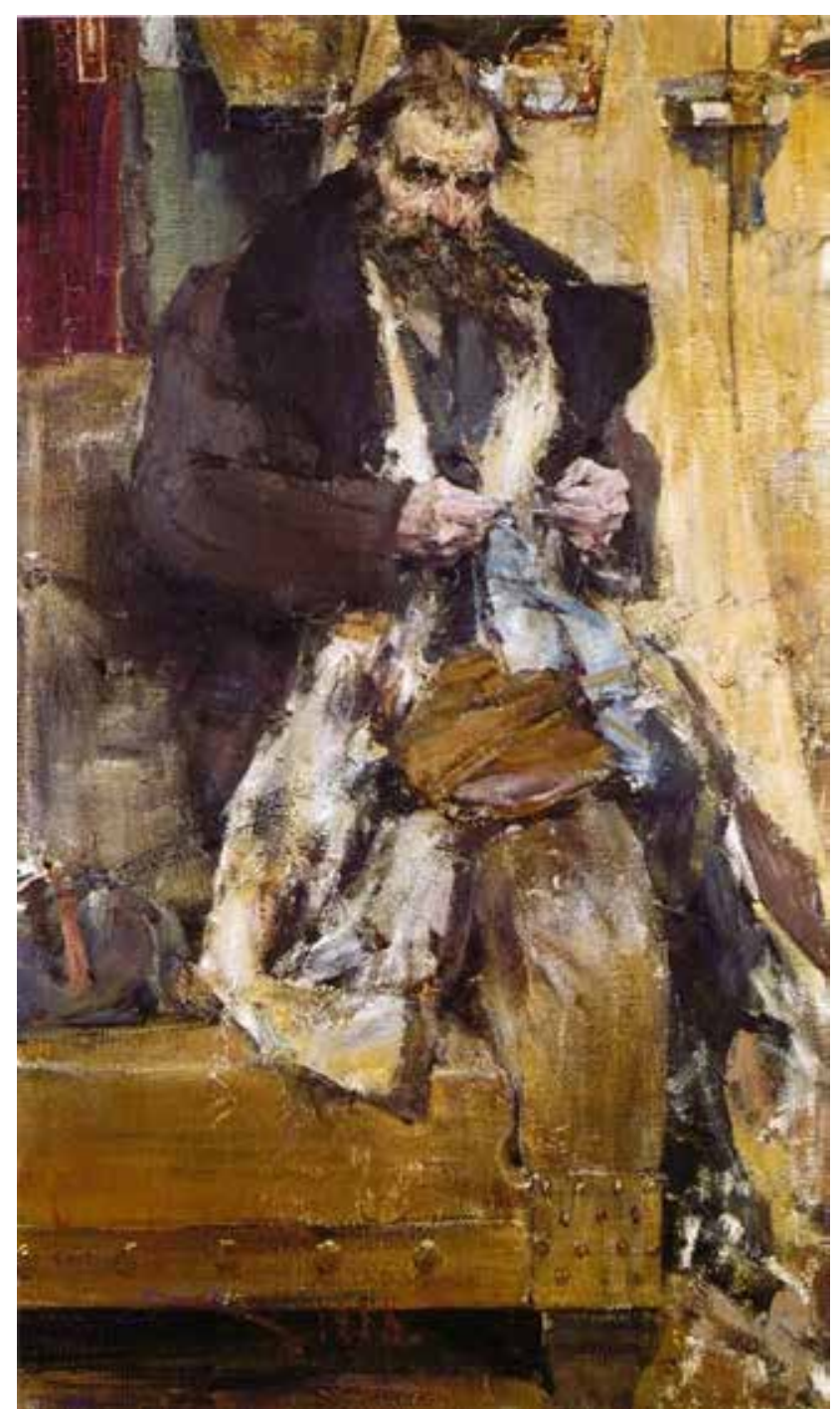

Илл. 13. Н.И. Фешин. «Портрет отца». 1918 г. Холст, масло, 162,0 × 96,0 см // Государственный музей изобразительных искусств Республики Татарстан (г. Казань)

и приятие жизни со всеми ее тяготами. Одним из самых сильных фешинских портретов дореволюционного периода можно считать «Портрет художника Виталия Гавриловича Тихова» (1916, СанктПетербургский Союз художников) (илл. 14).

Здесь создан образ человека сложного и противоречивого. В.Г. Тихов корректен и подтянут. Он производит впечатление человека умного, но неприятного и надменного. Склад его лица с холодными глазами и чувственным ртом сугубо индивидуален. Лицо некрасиво, но очень выразительно, со сложным комплексом противоречивых чувств и качеств. Как всегда, в портретах Н.И. Фешина динамична композиция.

Фигура расположена в левой части холста, так что срезается локоть. Художник стоит у кафельной печи, полузавешенной синей шалью с зеленоватыми, охристыми и красными пятнами. В.Г. Тихов в черном костюме с вишнево-красным галстуком и ослепительно-белыми воротничком и манжетами. Блестит золотая цепочка от часов. Мы здесь видим позу человека, свободно чувствующего себя в любом обществе. Хорошо написана рука. Портрет интересен слож-

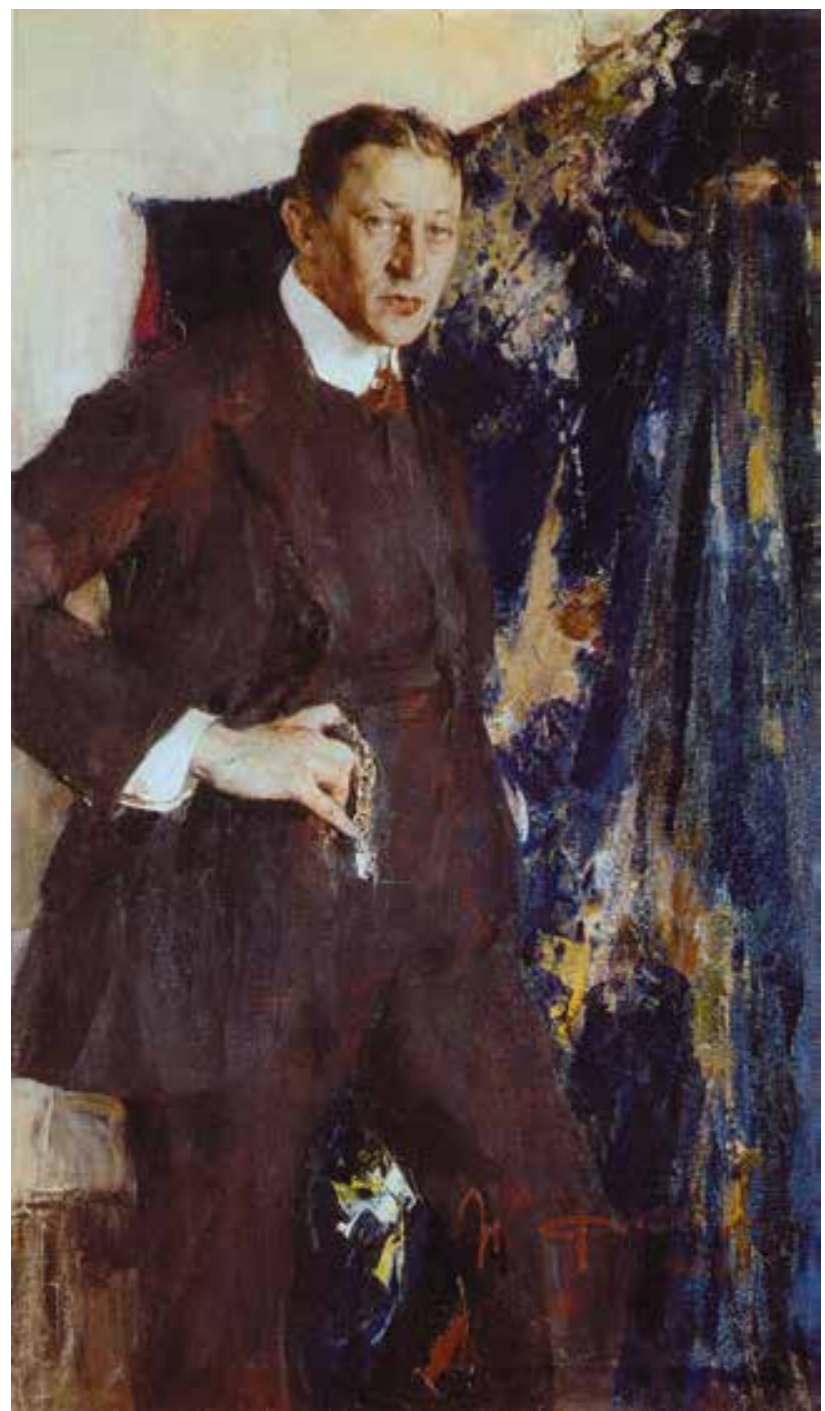

Илл. 14. Н.И. Фешин. «Портрет художника Виталия Гавриловича Тихова". 1916 г. Холст, масло, 144,0 × 86,0 см // Государственный Русский музей (г. Санкт-Петербург)

ной характеристикой, живописным мастерством, умелым рисунком и разработкой композиции. Со своими работами Н.И. Фешин не только участвовал на многих международных выставках, он в течение десяти лет (с 1912 по 1922 год) являлся экспонентом выставок передвижников. В 1916 году Н.И. Фешин был избран в члены Товарищества передвижных художественных выставок. В этом же году ему присвоили звание академика живописи. В первые годы после революции 1917 года Н.И. Фешин участвует в постановках народных театров. Он полон замыслов новых картин, об этом говорят его многочисленные эскизы, такие, как «Голод», «Кузница», «Восстание в тылу Колчака» и др. [6, с. 16]. Первая мировая война не оставила Н.И. Фешина равнодушным к событиям. Он сделал рисунки на военные темы, в которых показал раненых, тяжелые будни тыла (эскизы «Беженцы»), участвовал на выставках в пользу раненых и больных воинов [4, с. 9]. В 1922 году Н.И. Фешин тяжело заболел туберкулезом и по состоянию здоровья для лечения выехал за границу в Америку - 1 августа 1923 года. 
Трагически переживает художник свой отрыв от родины. Об этом говорят его письма к брату, которые хранятся в личном архиве художника в Казани. Его искусство за границей продолжает быть демократичным в своей основе и русским. Однако некоторые элементы салонности или манерности, которые проскальзывали в таких портретах, как портрет Е.Ф. Ошустович (1916), усиливаются. Их мы находим в некоторых живописных работах, а также в портретных рисунках детей. Вместе с тем, Н.И. Фешин создает ряд превосходных работ, таких, как портрет Д.Д. Бурлюка (1923), портрет гравера, старого актера и многие другие.

В этих портретах есть острота, характерность и большая глубина психологической характеристики. Они гармоничны по цветовому содержанию. За границей Н.И. Фешин становится популярным портретистом, у которого не было недостатка в заказах. Н.И. Фешин был виртуозом в искусстве и щедро делился своим мастерством с учениками. Многие его ученики стали известными советскими художниками, которые вспоминали своего учителя с большой теплотой и благодарностью. Незадолго до своей смерти у него возникла идея подарить художественному музею в Казани что-либо из своих работ, но данному намерению не суждено было осуществиться. Скончался Н.И. Фешин 5 октября 1955 года в Лос-Анжелесе.

Таким образом, как художник Н.И. Фешин сформировался в России, и прежде всего он русский мастер. В Америке его имя прочно связывают с региональной художественной школой Юго-Запада, и Н.И. Фешин, безусловно, входит в контекст искусства США. В России его, ученика И.Е. Репина, можно было бы поставить в один ряд с Ф.А. Малявиным, А.Е. Архиповым и С.В. Малютиным. Однако, в отличии от своего учителя И.Е. Репина, у него мы встречаем обостренное внимание к индивидуальности портретируемого, композиционную динамику, порой фиксацию какого-то мгновенного состояния человека. Картины Н.И. Фешин писал быстро и с большой легкостью. В станковых портретах, как и в его картинах, можно отметить крепкий рисунок, четкое композиционное построение. И, наконец, он был очень способным педагогом. Среди его учеников были такие советские художники, как П.А. Радимов, В.К. Тимофеев, П.И. Котов, Ф.А. Модоров, А.В. Григорьев и многие другие.

\section{Список литературы:}

1. Burliuk M. N.I. Feshin - Great Painter (his life and works in USA, 1923-1956). Color and Rhyme. 1958. № 35 . P. 5.

2. Дульский П.И. Николай Иванович Фешин : Очерк. Казань : Казанское отделение государственного изд-ва, 1921. 31 с.: ил.

3. Каталог произведений Н.И. Фешина до 1923 года / М-во культуры ТССР, Гос. музей изобразит. искусств Респ. Татарстан; [авт. вступ. ст. и сост. Е.П. Ключевская]. Казань : Тат. газ.-журн. изд-во, 1992.50 с.: ил.

4. Николай Иванович Фешин : каталог выставки / Музей изобразительных искусств ТАССР; [сост. Г.А. Могильникова]. Казань : [б. и.], 1963. 83 с.: ил.

5. Николай Иванович Фешин // Очерки по истории русского портрета конца 19-начала 20 века. Москва : Искусство, 1964. С. 277-294.

6. Николай Иванович Фешин: документы, письма, воспоминания о художнике / [сост. и авт. коммент. Г.А. Могильникова; авт. вступ. статьи С.Г. Капланова]. Л. : Изд-во «Художник РСФСР», 1975. 170 с.: ил.

7. Тулузакова Г.П. Русский американец Николай Фешин. Искусство. 2004. № 3. С. 59-63.

8. Тулузакова Г.П. Николай Фешин: Казань - Санта-Фе. К 1000-летию Казани. Третьяковская галерея. 2005. № 2. C. 15-20.

9. Яшина М.Г. Эскизы к картине Н.И. Фешина «Черемисская свадьба» из коллекции Козьмодемьянского художественного музея имени А.В. Григорьева // Вторые Казанские искусствоведческие чтения : материалы международной научно-практической конференции. К 130-летию со дня рождения Н.И. Фешина. Казань, 2-3 ноября 2011 г. Казань : «Центр инновационных технологий», 2014. С. 18-23.

10. Waters F. Nicolai Fechin. Arizona Highways. 1952. Vol. III. № 2. P. 22-34.

\section{References:}

1. Burliuk M. (1958) N.I. Feshin - Great Painter (his life and works in USA, 1923-1956). Color and Rhyme, no. 35 , p. 5.

2. Dul'skij P.I. (1921) Nikolaj Ivanovich Feshin: Ocherk. Kazan: Kazanskoe otdelenie gosudarstvennogo izd-va, 31 p.: il.

3. Katalog proizvedenij N.I. Feshina do 1923 goda (1992) / M-vo kul'tury TSSR, Gos. muzej izobrazit. iskusstv Resp. Tatarstan; [avt. vstup. st. i sost. E.P. Kljuchevskaja]. Kazan: Tat. gaz.-zhurn. izd-vo, 50 p.: il.

4. Nikolaj Ivanovich Feshin: katalog vystavki (1963)/Muzej izobrazitel'nyh iskusstv TASSR; [sost. G.A. Mogil'nikova]. Kazan': [b. i.], 83 p.: il.

5. Nikolaj Ivanovich Feshin (1964) Ocherki po istorii russkogo portreta kontsa 19-nachala 20 veka. Moscow: Iskusstvo, pp. 277-294.

6. Nikolaj Ivanovich Feshin: dokumenty, pis'ma, vospominanija o hudozhnike (1975) / [sost. i avt. komment. G.A. Mogil'nikova; avt. vstup. stat'i S.G. Kaplanova]. L.: Izd-vo «Hudozhnik RSFSR», 170 p.: il.

7. Tuluzakova G.P. (2004) Russkij amerikanets Nikolaj Feshin. Iskusstvo, no. 3, pp. 59-63.

8. Tuluzakova G.P. (2005) Nikolaj Feshin: Kazan - Santa-Fe. K 1000-letiju Kazani. Tret'jakovskaja galereja, no. 2 , pp. $15-20$.

9. Jashina M.G. (2014) Eskizy k kartine N.I. Feshina «Cheremisskaja svad'ba» iz kollektsii Koz'modem'janskogo hudozhestvennogo muzeja imeni A.V. Grigor'eva // Vtorye Kazanskie iskusstvovedcheskie chtenija: materialy mezhdunarodnoj nauchno-prakticheskoj konferentsii. K 130-letiju so dnja rozhdenija N.I. Feshina. Kazan', 2-3 nojabrja 2011 g. Kazan: Tsentr innovatsionnyh tehnologij, pp. 18-23.

10. Waters F. (1952) Nicolai Fechin. Arizona Highways, vol. III, no. 2, pp. 22-34. 